\title{
The predictive value of stimulation index calculated by modified mixed lymphocyte culture in the detection of G VH D following hematopoietic stem cell transplantation
}

Hematopoetik kök hücre naklini takiben gelişen GVHD'nin saptanmasında modifiye mikst lenfosit kültür testinde hesaplanan stimülasyon indeksinin belirleyici değeri

Hülya Sayılan Şen¹, Tülay Kılıçaslan Ayna², Hayriye Şentürk Çiftçi2, Sevgi Kalayoğlu Beşışık³, Emel Ayşe Önal' ${ }^{4}$ Arzu Akçay, Hülya Bilgen5, Mehmet Gürtekin2, Deniz Sargın³, Mahmut Çarin²

1Department of Hematology, Bakırköy Maternity and Children's Diseases Hospital, İstanbul, Turkey

2Department of Medical Biology, Istanbul University, Istanbul Medical Faculty, İstanbul, Turkey

3Department of Internal Medicine, Division of Hematology, Istanbul University, Istanbul Medical Faculty, İstanbul, Turkey

4Department of Public Health, Istanbul University, Istanbul Medical Faculty, İstanbul, Turkey

5Blood Bank, Istanbul University, Cerrahpaşa Medical Faculty, İstanbul, Turkey

\begin{abstract}
O bjective: Mixed lymphocyte culture (MLC) is one of the routine tests performed prior to hematopoietic stem cell transplantation (H SCT) as a predictive assay for assessing the quality of donor matching and graftversus-host disease (GVHD). The stimulation index is one of the formulas of the MLC test, and it is used for evaluation of matching between donor and recipient. Modified MLC (MMLC) test is produced by adding various cytokines to the MLC test, and increased sensitivity has been reported with this modification.

Materials and Methods: The importance of the stimulation index values in MLC and $\mathrm{MMLC}$ tests was evaluated in 59 patients who received H SCs from human leukocyte antigen-identical sibling donors. In the mMLC test, cytokines were added as interleukin (IL)-2, IL-2 + IL-4 and IL-2 + interferon (IFN)-gamma + tumor necrosis factor (TNF)-alpha. Stimulation index values in mMLC test were compared with stimulation index values in MLC test.

Results: Twenty-three (39\%) patients developed GVHD. When evaluated in terms of stimulation index $>1$ patients, in MLC, 55\% of the patients developed GVH D ( $p=0.229)$, whereas these values were $75 \%$ in the IL-2 added mMLC test $(p=0.035), 100 \%$ in the IL-2 + IL -4 added mMLC test $(p=0.076)$ and $85.7 \%$ in the IL-2 + IF N-gamma + TNF-alpha added mMLC test $(p=0.015)$.

Conclusion: MMLC increased the sensitivity of the test. The relation between the positive results and evidence of G VH D after transplantation was found significant. (Turk J Hematol 2010; 27: 263-8)

Key words: Stimulation index, mixed lymphocyte culture, hematopoietic stem cell transplantation, cytokines
\end{abstract}

Received: July 5, 2009

Accepted: J une 21, 2010 
Sen et al.

\section{Özet}

Amaç: Mikst lenfosit kültür testi hematopoetic kök hücre naklinden önce, donör uyumunu ve graft versus host hastalı̆̆ını önceden belirlemek amacı ile yapılan bir testtir. Stimülasyon indeksi mikst lenfosit kültür testinde kullanılan formüllerden biridir ve alıcı ile verici arasındaki uyumu belirlemek için yapılır. Modifiye mikst lenfosit kültür testi ise mikst lenfosit kültür testine çeşitli sitokinlerin ilave edilmesiyle yapılır ve yapılan bu değişiklikle duyarlılıkta artış olduğu saptanmıştır.

Yöntem ve Gereçler: HLA uyumlu donörden hematopoetik kök hücre nakli yapılacak 59 hastada Mikst Lenfosit Kültürr ve Modifiye Mikst Lenfosit Kültürdeki stimülasyon indeksi değerlerine bakılmıstır. M odifiye mikst lenfosit kültür testinde sitokinler interlökin-2, interlökin-2 + interlökin-4 ve interlökin-2 + interferon-gama + tümör nekrozis faktör-alfa seklinde eklenmis ve modifiye mikst lenfosit kültüründeki stimülasyon indeksi değerleri, mikst lenfosit kültüründeki stimülasyon indeksi değerleriyle karşılasstırılmıstır. Bulgular: Yirmi ücc hastada (\%39) graft versus host hastalığı oluşmuștur. Mikst lenfosit kültürde stimülasyon indeksi > 1olan hastalara bakıldığında hastaların \%55'inde graft versus host hastalığı görülmüştür (p:0,229). B unun yanı sıra interlökin-2 illavesi ile yapılan modifiye mikst lenfosit kültür testinde stimülasyon indeksi > 1 olan hastaların $\% 75$ 'inde $(p=0,035)$; interlökin-2 + interlökin-4 ilavesi ile yapılan modifiye mixt lenfosit kültür testinde stimülasyon indeksi $>1$ olan hastaların $\% 100$ 'ünde $(p=0,076)$ ve interlökin-2 + interferon-gama + tümör nekrozis faktör-alfa ilavesi ile yapılan modifiye mixt lenfosit kültür testinde stimülasyon indeksi $>1$ olan hastaların $\% 85,7$ 'sinde $(p=0,015)$ graft versus host hastalığı görülmüsstür.

Sonuç: Modifiye mikst lenfosit kültür, testin duyarlılığını arttırmıştır ve pozitif sonuçlar ile transplantasyondan sonra graft versus host hastalığının gelişmesi arasındaki ilişki anlamlı bulunmuştur.

(Turk J Hematol 2010; 27: 263-8)

Anahtar kelimeler: Stimülasyon indeksi, mikst lenfosit kültür, hematopoetik kök hücre nakli, sitokinler

Geliş tarihi: 5 Temmuz 2009

Kabul tarihi: 21 Haziran 2010

\section{Introduction}

Receiving a hematopoietic stem cell transplantation (HSCT) from a matched donor is a lifesaving treatment modality in some diseases. The degree of human leukocyte antigen (HLA) donor/recipient match has a significant association with graft-versus-host disease (GVHD). To date, donor selection has been based on match for the antigens encoded by the HLA class I $(A, B, C)$ and class II (DR) loci. Unrecognized or undefined mismatch for class II genes between the donor and recipient can exist despite a match for HLA-A, B, C and DR and could contribute to the high risk of GVHD after transplantation. Mixed lymphocyte culture (MLC) test is a method used in determination of class II antigens that evaluates cell proliferation based on compatibility of HLA antigens between the recipient and donor. MLC is a cellular test that exhibits the appropriateness of HLA antigens of the donor/recipient. One of the formulas used for this evaluation is the stimulation index (SI) [1,2]. However, the MLC test fails to detect the minor histocompatibility antigens contributing to GVHD and tissue rejection and also the response stimulated by HLA-DP. On the other hand, it is reported that GVHD and tissue rejection could be predicted by cytokine-modified mixed lymphocyte culture (mMLC) test [3-6]. Cytokines play a critical role after allogeneic recognition in the
MLC. The MLC is not only a clinical method in HSCT but also an important model to show T cell activation and cytokine interaction following alloantigen recognition. The $\mathrm{T}$ helper 1 cytokine interferongamma (IFN- $\gamma$ ) is known to induce cytotoxic T lymphocytes (CTL) by enhancing the expression of both HLA class I and class II molecules. Synergistic effects of interleukin-2 (IL-2) as well as tumor necrosis factor-alpha (TNF- $\alpha$ ) on the production of IFN- $\gamma$ are supposed, whereas IFN- $\gamma$ itself also shows a stimulatory influence on the expression of the IL-2 receptor in T lymphocytes [7].

Interleukin-4 (IL-4) is the developmental factor for B-lymphocytes and among the molecules that establishes association with HLA class II products $[5,6]$. TNF- $\alpha$ activates leukocytes, particularly neutrophils [8]. In both murine and human MLC reactions, TNF- $\alpha$ enhances the proliferative response [9].

In this study, cytokine-spiked mMLC test in addition to the MLC test were administered to patientdonor pairs. In MMLC, cytokines were added to the test individually or in combination. The probability of GVHD was thus determined by stimulating the antigens that were not exhibited in MLC, with an in vivo test. The association of SI results obtained from the MLC and MMLC tests with GVHD development was investigated. The relation between mMLC results and grade or organ involvement of GVHD was not considered. 


\section{Materials and Methods}

MLC and MMLC tests were performed in a total of 59 full match-related, recipient and donor pairs at Istanbul University Medical Faculty, Medical Biology Department. These cases were received from eight different centers. Written informed consents were obtained from all patients or their parents. This study was approved by local ethics committee.

Allogeneic HSCT was performed from full matchrelated donors, and bone marrow was used as HSC sources for each patient.

The conditioning regimen was changed according to the underlying disease and was mainly with busulfan and cyclophosphamide (BU/CY). In patients with multiple myeloma, the regimen consisted of high-dose melphalan. In patients with hemoglobinopathy and aplastic anemia, antithymocyte globulin (ATG) was incorporated into the regimen.

GVHD prophylaxis consisted of cyclosporin A (CsA) + short course methotrexate (MTX) in all cases.

The diagnostic tests for GVHD usually depended on the symptoms, but could include: gastrointestinal endoscopy, with or without a biopsy, liver function tests (aspartate aminotransferase [AST], alkaline phosphatase [ALP] and bilirubin levels are increased), liver biopsy (if the patient only has liver symptoms), lung X-rays, and skin biopsy $[10,11]$.

The MLC test was administered in one-way and two-stage manner (recipient and donor) in the culture laboratory of the department. In this study, we evaluated donor-directed. The peripheral blood mononuclear cells of the recipient and donor pairs were obtained via Ficoll Hypaque gradient centrifuge method. The lymphocytes obtained were washed three times with RPMI 1640 (with glutamine, Hepes, Sigma-50 u/ml penicillin and $50 \mu \mathrm{g} / \mathrm{ml}$ streptomycin) consequently followed by counting the cells in a medium containing RPMI 1640 and human serum (9:1). Donor lymphocytes were used at a final concentration of $1 \times 10^{6} \mathrm{cell} / \mathrm{ml}$. Recipient lymphocytes were used at a final concentration of $2 \times 10^{6} \mathrm{cell} / \mathrm{ml}$. The recipient cells were irradiated at $5000 \mathrm{rad}$ (cGy). Donor cells (100 $\mu \mathrm{l})$ and irradiated recipient cells $(50 \mu \mathrm{l})$ were added to the culture plates. All experiments were performed in triplicate. Results were normalized and presented as means. Cytokines were added in the same way in addition to MLC test, by producing cell batch (IL-2: $2.4 \mathrm{U} / \mu \mathrm{l}$, IL-4: $14.5 \mathrm{U} / \mu \mathrm{l}, \mathrm{IFN}-\gamma: 200 \mathrm{U} / \mu \mathrm{l}, \mathrm{TNF}-\alpha: 100 \mathrm{U} / \mu \mathrm{l})$ (Table 1).

$3 \mathrm{H}$ Thymidine was placed in each well after the cells were incubated in 96-well plates for 96 hours (h) at $37^{\circ} \mathrm{C}$ and $5 \% \mathrm{CO}_{2}$. All the cells were collected after 16-18 h. Cultures were harvested onto glass fiber filters. Glass fiber filters are dried at room temperature. The numeric information is defined in $\beta$ counter (Packard Tricarb 1000 TR) by placing filter papers in scintillation solution (toluol $+2,5$ diphenyl oxazole). Blank values are deducted from the measurements. Sample filters were counted using $\beta$ counter. SI formula was used for evaluation of the results. On the MLC test, a SI value $\leq 1$ indicates that the donor is not reactive to the recipient.

\section{$\mathrm{SI}=\mathrm{DR} * / \mathrm{DD}$}

Statistical analyses were performed using SPSS 10.0 statistical software program. The relationship between development of GVHD and MLC/mMLC was analyzed with Fisher's exact and Independent Samples T Test.

\section{Results}

The mean age of the 59 patients who underwent MLC test and HSCT was 19.91 1.96 (1-51) and the mean age of the donors was $20.61 \pm 1.91$ (1-51). Forty-one percent of the patients were female $(n=24)$ and $59 \%$ were male $(n=35)$. The median age was $21.50 \pm 2.88$ (1-45) for the female patients and 20.51 22.53 (1-51] for the males. Twelve female recipients received stem cells from a female donor and 14 from a male donor, whereas 17 of the male recipients received stem cells from a female donor and 16 from a male donor. Eighteen patients were previously diagnosed with chronic myeloid leukemia (CML) and the rest of the group were as follows: 15 acute myeloid leukemia (AML), 9 aplastic anemia, 7 acute lymphoid

Table 1. Localization of the cells on the culture plate on the MLC and $\mathrm{mMLC}$ test

\begin{tabular}{llll}
\hline MLC & MLC & mMLC & mMLC \\
\hline Donor-Donor & Donor-Recipient* & DD + IL-2 & DR* + IL-2 \\
(DD) & (DR) & DD + IL-2 + IL-4 & DR* + IL-2 + IL-4 \\
& & DD + IL-2 + IFN- $\gamma+$ TNF- $\alpha$ & DR* + IL-2 + IFN- $\gamma+$ TNF- $\alpha$ \\
\hline * & &
\end{tabular}

\footnotetext{
* irradiated cells
} 
leukemia (ALL), 3 thalassemia major, 3 multiple myeloma (MM), 2 non-Hodgkin lymphoma (NHL), 1 myelodysplastic syndrome (MDS), and 1 sickle cell anemia (Table 2).

Cytokine-spiked mMLC test was administered to recipient and donor pairs with an adequate number of cells.

GVHD developed in 23 (39\%) of the 59 patients who underwent HSCT. Acute and chronic GVHD were not classified or analyzed separately. The evaluation of the MLC test for SI in 59 patients

Table 2. Patient characteristics

\begin{tabular}{|c|c|c|}
\hline & $\mathbf{n}$ & $\%$ \\
\hline \multicolumn{3}{|l|}{ Age } \\
\hline \multicolumn{3}{|l|}{$\leq 15$ (Pediatric Group) } \\
\hline Male & 16 & 27 \\
\hline Female & 11 & 19 \\
\hline \multicolumn{3}{|l|}{ 15-51 (Adult Group) } \\
\hline Male & 19 & 32 \\
\hline Female & 13 & 22 \\
\hline \multicolumn{3}{|l|}{ Gender } \\
\hline Male & 35 & 59 \\
\hline Female & 24 & 41 \\
\hline \multicolumn{3}{|l|}{ Malignant Diseases } \\
\hline CML & 18 & 31 \\
\hline AML & 15 & 25 \\
\hline Aplastic Anemia & 9 & 15 \\
\hline ALL & 7 & 12 \\
\hline Thalassemia Major & 3 & 5 \\
\hline Multiple Myeloma & 3 & 5 \\
\hline $\mathrm{NHL}$ & 2 & 3 \\
\hline MDS & 1 & 2 \\
\hline Sickle Cell Anemia & 1 & 2 \\
\hline
\end{tabular}

revealed SI values $\leq 1$ in 50 patients, while 9 patients had SI values $>1$. In patients with SI values $\leq 1$, after transplantation, GVHD was detected in 18 patients and not detected in 32 patients. In the group with $\mathrm{SI}$ $>1,4$ had no complications while 5 had GVHD. The statistical evaluation of the association between the SI values and GVHD development revealed no significance $(p=0.229)$ (Table 3$)$.

mMLC test was performed by adding IL- 2 in 53 of these patients. While 45 patients revealed SI values $\leq 1$, 8 patients had SI values $>1$. While no GVHD was observed in 30 of the patients with $\mathrm{SI} \leq 1$, GVHD occurred in 15 patients. Six of the 8 patients with SI $>1$ developed GVHD while 2 patients did not. The statistical evaluation of the relation between SI values and GVHD development revealed a statistically significant result $(p=0.035)$ (Table 3$)$.

mMLC test was performed by adding IL-2+IL-4 in 24 of these patients. While 22 patients revealed $\mathrm{SI}$ values $\leq 1,2$ patients had SI values $>1$. While no post-transplant GVHD occurred in 17 of those patients with a $\mathrm{SI} \leq 1,5$ patients developed this disease. GVHD could be determined in 2 patients with SI $>1$. In the group spiked with IL-2+IL-4 cytokines, the statistical evaluation of the relation between $\mathrm{SI}$ values and GVHD development revealed a non-significant result $(p=0.076)$ (Table 3 ).

mMLC test was performed by adding IL-2+IFN$\gamma+$ TNF- $\alpha$ in 51 of the patient-donor pairs. While 44 patients revealed SI values $\leq 1,7$ patients had SI values $>1$. In 29 of those patients with $\mathrm{SI} \leq 1$, no posttransplant GVHD occurred, while 15 patients experienced GVHD. While it was not possible to determine GVHD in 1 patient with $\mathrm{SI}>1$, the disease had developed in the remaining 6 of those 7 patients. There was a statistically significant relation between SI values and GVHD development ( $p=0.015)$ (Table 3$)$.

Table 3. GVHD status and SI values calculated by MLC, MLC+IL-2, MLC+ IL-2+ IL-4, and MLC+ IL-2+ IFN- - + TNF- $\alpha$

\begin{tabular}{|c|c|c|c|c|c|c|c|c|c|c|c|c|c|}
\hline & & \multicolumn{3}{|l|}{ MLC } & \multicolumn{3}{|c|}{$M L C+I L-2$} & \multicolumn{3}{|c|}{$M L C+I L-2+I L-4$} & \multicolumn{3}{|c|}{$\begin{array}{l}\text { MLC+IL-2+IFN- } \gamma+ \\
\text { TNF- } \alpha\end{array}$} \\
\hline & & $\mathrm{SI} \leq 1$ & SI $>1$ & Total & SI $\leq 1$ & SI $>1$ & Total & SI $\leq 1$ & $\mathrm{SI}>1$ & Total & $\mathrm{SI} \leq 1$ & $\mathrm{SI}>1$ & Total \\
\hline \multirow[t]{2}{*}{ GVHD (-) } & $\mathrm{n}$ & 32 & 4 & 36 & 30 & 2 & 32 & 17 & 0 & 17 & 29 & 1 & 30 \\
\hline & $\%$ & 64.0 & 44.4 & (61.0) & 66.7 & 25 & (60.4) & 77.3 & 0 & (70.8) & 65.9 & 14.3 & $(58.8)$ \\
\hline \multirow[t]{2}{*}{ GVHD (+) } & $\mathrm{n}$ & 18 & 5 & 23 & 15 & 6 & 21 & 5 & 2 & 7 & 15 & 6 & 21 \\
\hline & $\%$ & 36.0 & 55.6 & (39.0) & 33.3 & 75 & (39.6) & 22.7 & 100 & $(29.2)$ & 34.1 & 85.7 & $(41.2)$ \\
\hline \multirow[t]{2}{*}{ Total } & $\mathrm{n}$ & 50 & 9 & 59 & 45 & 8 & 53 & 22 & 2 & 24 & 44 & 7 & 51 \\
\hline & $\%$ & 100 & 100 & $(100)$ & 100 & 100 & $(100)$ & 100 & 100 & $(100)$ & 100 & 100 & (100) \\
\hline \multicolumn{3}{|c|}{ Fisher's exact test } & \multicolumn{2}{|c|}{$p=0.229$} & & \multicolumn{2}{|c|}{$p=0.035$} & & \multicolumn{2}{|c|}{$p=0.076$} & & \multicolumn{2}{|c|}{$p=0.015$} \\
\hline
\end{tabular}


When the mean SI values obtained on the MLC and $\mathrm{mMLC}$ tests were evaluated with respect to GVHD development, the mean SI value of the 36 of the 59 patients undergoing MLC test who did not develop GVHD was 0.63 \pm 0.14 , while the mean SI value in the 23 patients who developed GVHD was $0.71 \pm 0.10$; the difference between the two groups was not significant $(p=0.956)$ (Table 4$)$.

The mean SI value of the 32/53 patients undergoing IL-2-spiked mMLC test who did not develop GVHD was $0.52 \pm 0.07$ while this value was $1.01 \pm 0.25$ in the 21/53 patients who did develop GVHD; the difference was statistically significant $(p=0.008)$ (Table 4).

The mean SI value of the 17/24 patients undergoing IL-2+IL-4-spiked mMLC test who did not develop GVHD was $0.59 \pm 0.05$, while this value was $2.44 \pm 1.87$ in the $7 / 24$ patients who did develop GVHD; the difference was statistically significant $(p=0.001)$ (Table 4).

The mean SI value of the 30/51 patients undergoing IL- $2+$ IFN- $\gamma+$ TNF- $\alpha$-spiked mMLC test who did not develop GVHD was $0.41 \pm 0.05$, while this value was $3.99 \pm 2.51$ in the $21 / 51$ patients who did develop GVHD; the difference was statistically significant $(p=0.005)$ (Table 4).

\section{Discussion}

Despite the technological and scientific advances in pre-transplant tissue typing tests and the fact that HSCT is performed between HLA-identical pairs, GVHD still represents the most significant

\begin{tabular}{|c|c|c|c|c|}
\hline & & GVHD (-) & GVHD (+) & $\mathbf{p}$ \\
\hline \multirow[t]{3}{*}{ MLC } & $\mathrm{n}$ & 36 & 23 & \multirow{3}{*}{0.956} \\
\hline & $\%$ & 61 & 39 & \\
\hline & $\mathrm{SI}$ & $0.63 \pm 0.14$ & $0.71 \pm 0.10$ & \\
\hline \multirow[t]{3}{*}{ MLC + IL-2 } & $\mathrm{n}$ & 32 & 21 & \multirow{3}{*}{0.008} \\
\hline & $\%$ & 60.4 & 39.6 & \\
\hline & $\mathrm{SI}$ & $0.52 \pm 0.07$ & $1.01 \pm 0.25$ & \\
\hline \multirow[t]{3}{*}{$\mathrm{MLC}+\mathrm{IL}-2+\mathrm{IL}-4$} & $\mathrm{n}$ & 17 & 7 & \multirow{3}{*}{0.001} \\
\hline & $\%$ & 70.8 & 29.2 & \\
\hline & $\mathrm{SI}$ & $0.59 \pm 0.05$ & $2.44 \pm 1.87$ & \\
\hline \multirow{3}{*}{$\begin{array}{l}\text { MLC + IL-2+ } \\
\text { IFN- } \gamma+\text { TNF- } \alpha\end{array}$} & $\mathrm{n}$ & 30 & 21 & \multirow{3}{*}{0.005} \\
\hline & $\%$ & 58.8 & 41.2 & \\
\hline & $\mathrm{SI}$ & $0.41 \pm 0.05$ & $3.99 \pm 2.51$ & \\
\hline
\end{tabular}

complication occurring after transplantation [12]. The possible reasons for this are thought to be polymorphic HLA determinants and/or minor histocompatibility systems not yet detected [6,13].

In the present study, the results from the MLC and cytokine-spiked mMLC tests were compared with regards to GVHD development in HSCT recipients. The association between GVHD development and SI values, as $\leq 1$ or $>1$, was investigated.

In mMLC, cell surface antigens were increased by providing treatment of stimulator cells with cytokines (IL-2, IL-4, TNF- $\alpha$, IFN- $\gamma$ ) that are known to increase the expression of HLA and non-HLA antigens. By adding exogenous cytokines to MLC cultures, amplification of weak proliferative responses was achieved. Using these amplifications, positive MLC reactions were frequently achieved amongst HLA-identical siblings $[6,7,14]$.

In a study by Bishara et al. [9], pre-determination of GVHD and tissue rejection was targeted by modifying the one-way MLC test. Three separate modifications were used in this study. In the first modification, IL-1 $\alpha$, IL-2 and IL-4 were added separately and in combination to the MLC test. Addition of IL-2 and IL-4 increased the MLC response in all unpaired controls and in certain HLA-identical pairs. The second modification was made by pre-treatment of the stimulator cells with IFN- $\gamma$, TNF- $\alpha$ and IL-4. This modification resulted in positive response in all the cases. The third modification was performed by readdition of cytokines to the MLC test where stimulator cells were pre-treated with added cytokines. As a result of this combined application, a high rate of positivity was also detected among the HLAidentical pairs. It was concluded that this result could be used in determining undetectable minor antigenic differences. The Bishara study reported that the mMLC study could be beneficial in choosing the most compatible donor in the presence of multiple HLA-identical donors.

In the study by Visentainer et al. [15], exogenous cytokines were added to the one-way MLC test. The investigators, thus intending to increase the sensitivity of the MLC test, stimulated the stimulator cells by IL-4 or IFN- $\gamma$ and added IL-2 or IL-4 to the responding cells at the start of the culture. By addition of different doses of cytokine in the autologous cultures and compatible recipient-donor cultures, advantageous results were obtained as compared to the MLC test. Their study revealed that pre-treatment of stimulator cells with IL-4 or IFN- $\gamma$ did not increase allogeneic response in the MLC test; however, IL-2 and IL-4 
addition at the start of the culture increased all the responses including the autologous response.

Another trial by Visentainer et al. [15] investigated the association between chronic GVHD occurring after SCT and the one-way MLC test. They found in that study that the MLC test was not adequate for predetermining acute GVHD; however, it could be the predictor of chronic GVHD when a result above Relative Response Index $(\mathrm{RRI})=4.5 \%$ was achieved.

As could be understood from the study conducted, the objective of modification of the MLC test is to predict post-transplant GVHD and tissue rejection. In our study, in addition to the MLC test, three different series were formed with addition of different cytokines. In the first series, IL-2 was added separately to the MLC test. In the second series, IL-2+IL-4 were added. In the third series, IL-2+IFN- $\gamma+$ TNF- $\alpha$ were added. In the mMLC tests, an increase was observed in the SI values. GVHD developed in 39\% of the patients undergoing HSCT. GVHD was detected in $55.6 \%$ of the group with $\mathrm{SI}>1$ in the MLC test, while these figures were $75.6 \%, 100 \%$ and $85.7 \%$, respectively, in the series spiked with IL-2, IL-2+IL-4 and IL-2+IFN- $\gamma+$ TNF- $\alpha$ [15].

When the mean SI values obtained on the MLC and $\mathrm{mMLC}$ tests were evaluated with respect to GVHD development, in the cytokine-spike groups, the statistical evaluation of the relation between mean SI values and GVHD development revealed significant results.

In conclusion, the MMLC test sensitized by addition of IL- 2 and IL-2+IFN- $\gamma+$ TNF- $\alpha$ cytokines is important in determining post-transplant GVHD. We believe that studying the MMLC test could be beneficial in choosing the most compatible donor when multiple HLA-identical donors are present.

\section{Conflict of interest}

No author of this paper has a conflict of interest, including specific financial interests, relationships, and/or affiliations relevant to the subject matter or materials included in this manuscript.

\section{R eferences}

1. Speer SA, Semenza JC, Kurosaki T, Anton-Culver H. Risk factors for acute myeloid leukemia and multiple myeloma: a combination of GIS and case-control studies. J Environ Health 2002;64:9-16;35-6.

2. Tiercy JM. Molecular basis of HLA polymorphism: implications in clinical transplantation. Transpl Immunol 2002;9:173-80.
3. Parkman R, Rappeport J, Rosen F. Human graft versus host disease. J .Invest Dermatol 1980;74:276-9.

4. Petersdorf EW, Kollman C, Hurley CK, Dupont B, Nademanee A, Begovich AB, Weisdorf D, McGlave P. Effect of HLA class II gene disparity on clinical outcome in unrelated donor hematopoietic cell transplantation for chronic myeloid leukemia: the US National Marrow Donor Program Experience. Blood. 2001;98:2922-9.

5. 5-Malkovský M, Loveland B, North M, Asherson GL, Gao L, Ward P, Fiers W. Recombinant interleukin-2 directly augments the cytotoxicity of human monocytes. Nature. 1987;325:262-5.

6. Tanaka J, Imamura M, Kasai M, Kobayashi S, Hashino S, Kobayashi H, Sakurada K, Miyazaki T. Cytokine gene expression in the mixed lymphocyte culture in allogenic bone marrow transplants as a predictive method for transplantation-related complications. $\mathrm{Br}$ J Haematol 1994;87:415-8.

7. Danzer SG, aCampo C, Rink L. Interferon-gamma plays a key role in the human mixed lymphocyte culture. Bone Marrow Transplant 1996;18:991-6.

8. Matthews SJ, Sullivan JS. A role for tumour necrosis factor-alpha in the human mixed lymphocyte culture reaction. Immunol Cell Biol 1992; 70:107-10.

9. Bishara A, Brautbar C, Nagler A, Slavin S, Leshem B, Cohen I, Kedar E. Prediction by a modified mixed leukocyte reaction assay of graft-versus-host disease and graft rejection after allogeneic bone marrow transplantation. Transplantation 1994;57:1474-9.

10. Przepiorka D, Weisdorf D, Martin P, Klingemann HG, Beatty P, Hows J , Thomas ED. Consensus conference on acute GVHD grading. Bone Marrow Transplant 1995; 15:825-8.

11. Rowlings PA, Przepiorka D, Klein JP, Gale RP, Passweg J R, Henslee-Downey PJ, et al. IBMTR Severity Index for grading acute GVHD: retrospective comparison with Glucksberg grade. Br J Haematol 1997;97:855-64.

12. Storb R, Thomas ED. Allogeneic bone-marrow transplantation. Immunol Rev 1983;71:77-102.

13. Pawelec G, Müller C, Ehninger G. Predictive strength of mixed lymphocyte cultures for acute graft-versus-host disease in patients transplanted with HLA-identical sibling bone marrow. Transplantation 1989;48:890-1.

14. Pawelec G, Baumgartner P, Rehbein A, Reusch U, Schaudt K. Cytokine regulation of the balance between alloindifferent and allospecific suppressor induction in mixed Iymphocyte cultures. Transplantation 1990;49:615-9.

15. Visentainer JE, Lieber SR, Persoli LB, de Souza Lima SC, Vigorito AC, Aranha FJ , Eid KA, Oliveira GB, Miranda EC, de Souza CA. Correlation of mixed lymphocyte culture with chronic graft-versus-host disease following allogeneic stem cell transplantation. Braz J Med Biol Res 2002;35:567-72. 